\title{
5. The adjudication of the right to health
}

\section{INTRODUCTION}

The goal of chapter four was twofold: to identify the limitations of the right to health under the predominant interpretation, and to offer an alternative understanding based on the notion of solidarity. The chapter showed that the predominant interpretation offers little protection to social rights when they are understood in line with solidarity. On the other hand, if it is true that solidarity has any connection to social rights, upgrading the right to health through justiciability, might come at the cost of transmuting its main features. And if that is so, social rights might not be able to evolve towards universality, integration, interrelatedness, indivisibility and protection on an equal footing with all human rights.

While chapter four advanced solidarity as an alternative justification for the right to health, the present chapter explores different interpretative understandings of the right to health at the case law level. The purpose of this inquiry is to examine court decisions in access-to-healthcare cases to establish salient case law trends and determine whether any of these trends protects the right to health in line with solidarity, as portrayed in the second half of chapter four.

Two trends in case law are considered. One that looks at the right to health as an individual legal right, and another that focuses on the right to health in line with solidarity. Within the first focus, two main sub-trends can be detected depending on whether courts have protected the right to health either indirectly or directly.

The indirect protection of the right focuses on cases where the right to health has been protected via other human rights. Such an indirect understanding is performed on the assumption that not only is there no watertight division between both sets of rights, ${ }^{1}$ but also that social rights such as the right to

1 On the basis of the Airey case (Airey v Ireland (1979) Series A no 2 EHRR 305), many scholars understand the scope of social rights within the framework of the predominant interpretation, eg, Maite San Giorgi, The Human Right to Equal Access to Health Care (Intersentia 2012) 109 and Ingrid Leijten, Core Socio-Economic Rights and the European Court of Human Rights (CUP 2018) 41-42. 
health can acquire protection. ${ }^{2}$ The rights involved in this process include the right to life, but also other rights such as the right to property, security, physical integrity and privacy, education and information, housing, food, and work or the prohibition of cruel, inhuman or degrading treatment. ${ }^{3}$ In my analysis, I have limited myself mostly to the right to life and the prohibition of inhuman treatment. Due to the assistance the right to health receives from other rights for its protection, I have labelled the protection received by the right to health as 'collateral' or 'indirect'. 4

The main objection I explore with respect to this indirect approach is that although medically speaking it makes sense to relate poor health to the curtailment of life, the extent to which such a link confirms a legal relationship is unclear. I begin by asking: when is one right successfully applied in the service of another? While a legal relationship does not require the rights to life and health to be identical, for a symbiotic relationship the distinctive constitutive elements of the right to health would need to become enforced. In other words, I depart from the assumption that for a collateral or indirect approach to be regarded as successful, the supporting right (the right to life) must articulate the protection of the supported right (the right to health). More specifically, the supporting right needs to actively engage in the protection of the normative content, means of redress and legal scope of the supported right. In this respect, it seems safe to argue that if the main components of the right to health attain legal protection, it matters little whether this happens through a direct adjudication or, indirectly, via other human rights. Yet, if the elements of the supporting right are the only ones attaining protection while those of the supported right are not, would that be a symbiotic legal relationship? In other words, is the right to health evolving along a path of its own?

Under the direct individual approach, the right to health is often protected in line with the value of human dignity. The study poses two critical questions in this regard. First, does this interpretative effort fit the natural trade-offs the institutions in charge of providing healthcare services are regularly confronted with? As analysed in the previous chapter, these trade-offs involve contra-

2 Eva Brems, 'Indirect Protection of Social Rights by the European Court of Human Rights' in Daphne Barak-Erez and Aeyal Gross (eds), Exploring Social Rights. Between Theory and Practice (Hart Publishing 2007) 137.

3 Brigit Toebes, The Right to Health as a Human Right in International Law (Intersentia 1999) 260; Stephen Marks, 'The Emergence and Scope of the Human Right to Health' in Jose Zuniga, Stephen Marks and Lawrence Gostin (eds), Advancing the Human Right to Health (OUP 2013) 311-17.

4 A label I borrow from Colin Warbrick, see Colin Warbrick, 'Economic and Social Interests and the European Convention on Human Rights' in Mashood Baderin and Robert McCorquodale (eds), Economic, Social and Cultural Rights in Action (OUP 2007) 247. 
dicting claims in a context of scarce resources. Secondly, I ask if a legal right to health can ever protect the integrity of the public healthcare system. More specifically, I ask whether these elements remain unavoidably confined to the lower status of aggregated demands, namely, claims that must always bow to the fundamentality of individual interests that coincide with the scope of classical rights.

As already mentioned, I also look at a second set of cases that go beyond the rationale of individual legal rights and which seem to fit with the principle of solidarity. Instantiations of this trend are enforced whenever courts corroborate legislative formulations concerning access to healthcare, something they can do either by: (1) striking down administrative acts that deprive a person from enjoying a healthcare provision to which he or she was entitled based on a previous legislative standard; or (2) upholding an administrative act that rejects the enjoyment of a healthcare provision following a legislative standard in force.

As was noted in the previous chapter, solidarity leads primarily to a legislative understanding of the right to health. As explained, this was not because of parliamentary infallibility in upholding this notion of social rights. The main reason is that only in the generality of legislation can there be room to address problems of distributive justice, namely, a focus that aims not to the position of the isolated individual but on what everyone in the community owes to everyone else.

Yet, in a development that resembles the prohibition of retrogression, ${ }^{5}$ I argue that the outlawing of legislative healthcare provisions by the judiciary is also a possibility within this trend: courts can strike down an administrative act or legal statute in order to respect, protect or fulfil the right to health under solidarity. This happens when the statute challenges the solidarity embedded in the healthcare system. In this case, the court can reinstate a former healthcare provision that better aligns with this criterion. The court uses solidarity as a guideline that operationalizes the progressive realization of the right to health. The judiciary realizes this human right by making its way on the long road towards equal access to healthcare for all. Namely, it vetoes attempts to condition access to healthcare to economic privilege. However, because of the democratic pedigree of social rights, the judiciary cannot operate actively

5 The prohibition of retrogression is a remedial tool envisioned by General Comment 3 (UNCESCR, 'General Comment 3: The Nature of States Parties' Obligations (Art 2, Para. 1, of the Covenant)', UN Doc E/1991/23, 14 December 1990, para 9). Although there are resemblances with the perspective I suggest here, by the end of the chapter I shall argue why only certain understandings of this notion appear to fit this remedy. 
but only reactively. It can only review a legislative decision, not generate new policy.

I am interested in exploring whether courts have understood the question posed by the right to health as something beyond whether A has an entitlement to X. If, according to solidarity, the obligation to fulfil the right to health consists of protecting a non-marketed right, I ask whether courts find it problematic that although both A and B live under the same legislative authority, A's right of access to healthcare can entail a substantively greater scope and quality than that of B's.

This question is assessed in the light of the two interpretations I have explored in this work: that of chapter two, where the right to health is an individual legal right, and that of the second half of chapter four, where the right to health's obligation to fulfil is a non-marketed collective right of access to a public service. The purpose of the present chapter is to assess the validity of the main claim of this study in a more empirical setting, namely, the idea that understanding the right to health from the angle of classic individual human rights may have negative consequences for the true nature of this right and the protection it can offer, which is collective. Secondly, and closely related to this claim, I consider whether only certain understandings about the role of the courts are representative of the right to health's collective nature. I claim that the individualistic definition of the right to health that courts have so far been fundamentally adjudicating is not representative of the distinctive nature of this right. The issue identified is not that this view is wrong per se. My claim is that the individualistic perspective fails to identify the essential fibre of social rights and the right to health.

I will start by making the case for the first trend, enriching my analysis by considering various noteworthy judicial decisions in the field of social rights and the right of access to healthcare. In doing so, my constant focus is on the prospects of enforcing the distinctive elements the right to health possesses. I have not sought to develop an exhaustive analysis of decisions regarding access to healthcare, or one which is limited to one exclusive jurisdiction or human rights system. I have simply tried to critically examine the main narratives and interpretations of salient decisions that can be found in this field. Further, applying the same methodology, I examine the second trend, which is perhaps more in line with the principle of solidarity. 


\section{REALIZING THE RIGHT TO HEALTH UNDER THE PREDOMINANT INTERPRETATION}

\subsection{The Right to Health and Other Human Rights: A Symbiotic Relationship?}

The existence of different normative goals between the right to life and the right to health respectively, do not render the collateral or indirect protection of social rights impossible. On the contrary, attaining the realization of the supported right (right to health) with a supporting right (right to life) supposes the existence of different normative goals. ${ }^{6}$ Hence, the challenge is to determine whether, despite these different normative goals, the supporting right can become an appropriate auxiliary mechanism for the protection of the core elements of the supported right. If the supporting right actively engages in the protection of the normative content, means of redress and legal scope of the supported right, one could be satisfied that the relationship is efficient, conducive or symbiotic, so to speak.

In this regard, Toebes suggests that although from a medical point of view it makes sense to relate health to life, such a link does not prove the existence of a legal relationship between the right to life and the right to health when considered from the perspective of its distinctive elements. ${ }^{7} \mathrm{Be}$ that as it may, protection of the right to health has been attempted indirectly, most notably in the aftermath of landmark decisions adopted by India's Supreme Court in the 1980s. ${ }^{8}$

In the case of the right to life, this right's normative goals involve two dimensions: a negative and a positive dimension. From a negative point of view, the right to life requires the State to refrain from depriving persons of their life arbitrarily. ${ }^{9}$ From a positive point of view, the right to life entails an obligation

\footnotetext{
6 Warbrick (n 4) 241-42.

Toebes (n 3) 259.

8 In a case involving torture, the Supreme Court of India regarded the right to health a fundamental right embedded within the right to life, see Francis Coralie Mullin $v$ The Administrator, Union Territory of Delhi \& Ors [1981] INSC 12, 19812 SCR 516 (Supreme Court of India); something similar was held in Paramanand Katara $v$ Union of India \& Ors [1989] INSC 254, (1989) 4 SCC 286 (Supreme Court of India) (Katara), a case where emergency medical care was not granted; Michael Langford, 'The Justiciability of Social Rights: From Practice to Theory' in Michael Langford (ed), Social Rights Jurisprudence: Emerging Trends in International and Comparative Law (CUP 2008) 7.

9 In the context of the European Convention on Human Rights, this right is not a guarantee against all threats to life, but against intentional deprivation and careless
} 
for the State to safeguard human life. ${ }^{10}$ This latter obligation requires further obligations such as enacting criminal legislation, or the provision of police and prosecutorial mechanisms to deal with the criminal loss of life. ${ }^{11}$

As I analyse further on, it is under this second dimension that a link between the right to life and the right to health has been attempted: the right to health could be protected through positive obligations deriving from the right to life. ${ }^{12}$

The normative goal of the right to health is not the protection of life as such. Even if the approach of the right to life focuses on human life from a physical and psychical perspective, the right to health is not to be regarded as an individual right to be healthy. ${ }^{13}$ From the perspective of access to healthcare, the right to health must be made accessible in the event of illness. ${ }^{14}$ In developing this idea, General Comment 14 states that this duty contains entitlements, including 'the right to a system of health protection which provides equality of opportunity for people to enjoy the highest attainable level of health'. ${ }^{15}$

A preliminary conclusion is that the right to life would be compatible with the right to health when the supporting right leads to the enforcement of a system of health protection that can provide equality of opportunity.

\subsubsection{Means of redress}

When looking at the means of redress of the right to life and the right to health, an important overlap can be noted: the provision of healthcare. Healthcare is not the only output of the right to health - action on the social determinants of health is another important output. ${ }^{16}$ Yet, despite the necessary prioritizations, trade-offs and sacrifices required by the very nature of the provision of social rights, the right to health cannot be theorized without contemplating access to healthcare. ${ }^{17}$

endangering of life, see Pieter van Dijk and others (eds), Theory and Practice of the European Convention on Human Rights (Intersentia 2006) 352.

10 Osman v UK [1998] ECHR 101, (1998) 29 EHRR 245, para 116.

11 Rhona Smith, Textbook on International Human Rights (OUP 2007) 195.

12 ibid 196.

13 UNCESCR, 'General Comment 14 The Right to the Highest Attainable Standard of Health', UN Doc E/C.12/2004/4, 11 May 2000, para 8.

${ }_{14}$ International Covenant on Economic, Social and Cultural Rights (adopted 16 December 1966) 993 UNTS 3, art 12 (ICESCR).

15 UNCESCR, Comment 14 (n 13) para 8.

16 ibid paras 9-11; UNCHR, 'Report of the Special Rapporteur on the Right of Everyone to the Enjoyment of the Highest Attainable Standard of Physical and Mental Health, Paul Hunt', UN Doc E/CN.4/2006/48, 3 March 2006, paras 9, 10.

17 ICESCR (n 14) art 12; UNCESCR, Comment 14 (n 13) para 8; UNCHR, E/ CN.4/2006/48 (n 16) para 4; Toebes locates healthcare at the core of the right to health, see Toebes (n 3) 284. 
If lack of access to healthcare can affect the right to life, could the violation of the right to life not be put at the service of the right to health?

Courts have done this in several situations. They have reasoned that a person's life could be lost, threatened or severely undermined because of a lack of access to healthcare. Situations that fit this hypothesis include: emergency care,$^{18}$ protection of life while staying in medical care facilities, ${ }^{19}$ the right to a lifesaving drug, ${ }^{20}$ the avoidance of inhuman or degrading treatment ${ }^{21}$ or healthcare provided to persons deprived of liberty. ${ }^{22}$ Cases such as abortion,

\section{Katara (n 8).}

19 In a case of medical negligence leading to the death of a new-born baby after delivery complications, the European Court of Human Rights found that the right to life "enjoins the State not only to refrain from the "intentional" taking of life, but also to take appropriate steps to safeguard the lives of those within its jurisdiction'. It noted that 'those principles apply in the public-health sphere too. The aforementioned positive obligations ... require States to make regulations compelling hospitals, whether public or private, to adopt appropriate measures for the protection of their patients' lives', see Calvelli and Ciglio v Italy [2002] ECHR 3, paras 48, 49; in another case concerning an individual suffering from schizophrenia who was admitted to a State medical facility reporting symptoms of great distress that later made him jump from a sixth-floor window, the Court established that 'an operational duty arose to take reasonable steps to protect him from a real and immediate risk of suicide and that that duty was not fulfilled', see Reynolds $v$ The United Kingdom [2012] ECHR 437, (2012) 55 EHRR 35, para 61.

20 Commenting on the Nitecki v Poland case (Nitecki v Poland App no 65653/01 (ECtHR, 21 March 2002) (Nitecki)) before the European Court of Human Rights (ECtHR), San Giorgi argues that irrespective of the fact that the complaint was ultimately dismissed, the right to a life-saving drug might be protected under Article 2, see San Giorgi (n 1) 103-104.

${ }_{21} \quad$ In $D$ v the United Kingdom (Dv the United Kingdom [1997] ECHR 25, (1997) 24 EHRR 423), the ECtHR ruled that expelling a person who suffered from an advanced stage of AIDS from the UK to St. Kitts (where the applicant was a national), after having served in prison for a criminal offence would entail a violation of Article 3 (inhuman treatment). San Giorgi comments that the ECtHR arrived at this decision setting a criteria whereupon it considers: (a) the severity of the individual's health condition, (b) whether the treatment was available in the host country, and (c) whether the applicant had children, family or other relatives to take care of him (see n 1, 105); in a case involving a four-limb-deficient thalidomide victim with numerous health problems including defective kidneys, the ECtHR considered that 'to detain a severely disabled person in conditions where she is dangerously cold, risks developing sores because her bed is too hard or unreachable, and is unable to go to the toilet or keep clean without the greatest of difficulty, constitutes degrading treatment contrary to Article 3 of the Convention', see Price v The United Kingdom [2001] ECHR 458, (2002) 34 EHRR 53, para 30 .

22 The Velikova case involved a person who died after having been apprehended by the police. Not accepting the Government's explanation that the individual died because of injuries after having fallen, the ECtHR held that 'Mr. Tsonchev died as 
gender-reassignment, infrequent availability of medical care, destruction of necessary asthma medication, denial of authorization to receive a doctor in a prisoner's cell and denial of authorization for examination in a hospital have also been mentioned. ${ }^{23}$ In these cases, courts have protected the individual's life by making healthcare accessible. At the outset, it would appear that the right to health, supported by the right to life, would acquire legal protection.

Yet, is the provision of healthcare a definitive indication that the right to health is being advanced? To some readers this may sound irrelevant - what is the need for demarcating theoretical distinctions when the purpose of healthcare will arguably always be the same? While, admittedly, healthcare fulfils the same function under any theorization - preventing, curing or rehabilitating - the right to health would be advanced only when in line with our preliminary conclusion, ie that a system of health protection based on equality of opportunity is advanced. ${ }^{24}$

a result of injuries inflicted while he was in the hands of the police'. Considering that no evidence was produced that the person's severe injuries were medically examined while in custody led the ECtHR to regard the situation as a violation of Article 2 (right to life). Velikova v Bulgaria [2000] ECHR 198, paras 74-76. In another case, the ECtHR established that police officers' awareness of the deterioration of the conditions of a detainee and failure to promptly contact medical care constituted a violation of Article 2, see Anguelova v Bulgaria [2002] ECHR 489, (2004) 38 EHRR 31, paras 125-31. In another case, concerning a prison inmate suffering from a chronic mental disorder which involved psychotic episodes and feelings of paranoia, the ECtHR established that 'the lack of effective monitoring of Mark Keenan's condition and the lack of informed psychiatric input into his assessment and treatment disclose significant defects in the medical care provided to a mentally ill person known to be a suicide risk'. The ECtHR regarded that the application of a disciplinary punishment in those circumstances amounted to a violation of Article 3 of the Convention, see Keenan $v$ The United Kingdom [2001] ECHR 242, (2001) 33 EHRR 38, para 116; under the framework of the International Covenant on Civil and Political Rights, the UNHRC found a violation of Article 6(1) and of Article 10(1). The case involved the detention of Mr Vladimir Lantsov in a Russian prison. The health condition of the detainee rapidly deteriorated due to the overcrowding of the prison and the lack of adequate medical care. The Committee stated that that it was 'up to the State party [to organize] its detention facilities to know about the state of health of the detainees as far as may be reasonably expected. Lack of financial means cannot reduce this responsibility. The Committee considers that a properly functioning medical service within the detention centre could and should have known about the dangerous change in the state of health of Mr Lantsov. It considers that the State party failed to take appropriate measures to protect Mr Lantsov's life during the period he spent in the detention centre'. Yekaterina Pavlovna Lantsova on behalf of her son, Vladimir Albertovich Lantsov (deceased) $v$ The Russian Federation (15 April 2002) UN Doc CCPR/C/74/D/763/1997, para 9(2).

23 Warbrick (n 4) 251; San Giorgi (n 1) 99-100.

24 ch $2, \mathrm{n} 104$. 
Cases such as that of the prison inmate show that adjudications indirectly based on classical rights can lead to the same means of redress as the right to health. Yet, the extent to which these adjudication dynamics advance a system of health protection remains less clear. Admittedly, the prisoner is in a position of extreme vulnerability, a factual situation that could reflect the abovementioned equality of opportunity. On the other hand, to what extent can this argument be extended to justify something more than the relatively exceptional position of the prison inmate? Simply accepting the assumption that most people do not normally spend a period of their lives in jail, and that the frequency with which they visit healthcare institutions is far more common and ordinary, can the example of the prison inmate be sufficiently informative to build the foundations for a system of health protection equal and accessible to all?

\subsubsection{Classical inter-American case law}

So far I have shown that the normative content of the right to life is different from that of the right to health. Similarly, I have shown that even if the provision of healthcare can be the output of the right to life, the cases where this occurs are so limited that the existence of a symbiotic relationship between both rights remains inconclusive. In this Section, I will explore these dynamics in important cases decided by the Inter-American Court of Human Rights: the Yakye-Axa Indigenous Community $v$ Paraguay case ${ }^{25}$ and the Sawhoyamaxa Indigenous Community v Paraguay case. ${ }^{26}$ Further, I will look at some recent jurisprudential developments of the Court where it attempts to adjudicate the right to health on its own merits, namely, independently and without the assistance of a supporting right.

In the Paraguayan cases, the Court dealt with the situation of two indigenous communities living under extremely poor conditions. The two cases were rather similar. The members of the communities not only lacked access to health, education and water, their situation was also aggravated by their exposure to the natural elements and the geographical and economic obstacles hindering their access to medical health. The Court also found that the communities' right to property over their ancestral lands had been violated, as the State had not formally acknowledged that ownership. This increased the deprivation of the communities as they were impeded from fishing and hunting. Their level of destitution was such that in both cases some members of the

25 Case of the Yakye-Axa Indigenous Community v Paraguay (Merits, Reparations and Costs) Inter-American Court of Human Rights, 17 June 2005.

26 Case of the Sawhoyamaxa Indigenous Community $v$ Paraguay (Merits, Reparations and Costs) Inter-American Court of Human Rights, 29 March 2006. 
community died. This led the Court to the finding that Paraguay had violated the right to life of the inhabitants of the communities, ${ }^{27}$ and in some cases had even been directly responsible for the individual deaths. ${ }^{28}$

The Court's understanding of the positive obligations derived from the right to life is quite close to the area covered by the right to health. As already stated, for the collateral focus to be justified, both rights must be conceptualized as something different from one another. Yet, looking at the abovementioned Paraguayan cases dealt with by the Inter-American Court of Human Rights, it is difficult to see a marked conceptual contrast. The Court established a close link between the two rights, where the right to health appeared to be overlapping or to be some sort of sub-element of the right to life. Citing its jurisprudence, the Court affirmed that:

[T] he right to life is crucial in the American Convention, for which reason realization of the other rights depends on protection of this one. When the right to life is not respected, all the other rights disappear, because the person entitled to them ceases to exist. Due to the basic nature of this right, approaches that restrict the right to life are not admissible. ${ }^{29}$

The Court also opened room for the establishment of positive obligations emanating from the right to life:

Essentially, this right includes not only the right of every human being not to be arbitrarily deprived of his life, but also the right that conditions that impede or obstruct access to a decent existence should not be generated. ${ }^{30}$

27 In Sawhoyamaxa, the Court delimited the scope of the State's positive obligations. 'It is clear for the Court that a State cannot be responsible for all situations in which the right to life is at risk. Taking into account the difficulties involved in the planning and adoption of public policies and the operative choices that have to be made in view of the priorities and the resources available, the positive obligations of the State must be interpreted so that an impossible or disproportionate burden is not imposed upon the authorities. In order for this positive obligation to arise, it must be determined that at the moment of the occurrence of the events, the authorities knew or should have known about the existence of a situation posing an immediate and certain risk to the life of an individual or of a group of individuals, and that the necessary measures were not adopted within the scope of their authority which could be reasonably expected to prevent or avoid such risk.' ibid para 155; in Yakye-Axa, the Court relied on human dignity, see Yakye-Axa (n 25) paras 162, 168.

28 While this was not accepted in the Yakye-Axa case (Yakye-Axa (n 25) paras 177, 178), it was accepted in the Sawhoyamaxa case (Sawhoyamaxa (n 26) paras 176, 178).

29 Yakye-Axa (n 25) para 161.

30 ibid. 
Similarly, special account of the vulnerability of indigenous communities was taken by adding that the care of these groups 'becomes a high priority'. ${ }^{31}$ The interaction between the right to life and the right to health was one where the latter right was made a prerequisite of the former. However, the Court did not distinguish the ways in which the violations of these two different rights would occur. The Court limited itself to stating that 'special detriment to the right to health, and closely tied to this, detriment to the right to food and access to clean water, have a major impact on the right to a decent existence'. ${ }^{32}$

As reparation, the Court granted a community development fund and programme to supply drinking water and sanitation infrastructure, and a community development programme to implement education, housing, agricultural and health programmes for the benefit of the members of the community. ${ }^{33}$

\subsubsection{Assessment}

Looking at the nature of these reparations, it is unclear to what extent they differ from social policy measures. From the perspective of equality before the law, the fact that public policy measures are adopted on an ad hoc basis while other groups of persons may be suffering the consequences of structurally similar problems ${ }^{34}$ (which is different from stating that the entire population should be subject to identical social policies ${ }^{35}$ ) is something open to criticism. If the causes of the problem are rooted in structural social conditions such as poverty and marginalization, one can legitimately ask whether the dramatic reality of these indigenous communities is not being experienced equally by other indigenous communities but also, perhaps, by other groups or persons submitted to equally stringent forms of social vulnerability, discrimination and

\footnotetext{
$31 \quad$ Yakye-Axa (n 25) para 162.

32 ibid para 167.

33 ibid paras 205, 221.

34 In the 2016 Human Development Report, Paraguay ranks 110 within medium human development countries, one slot above Egypt and one slot below Gabon. In Latin American and the Caribbean region, El Salvador (117), Bolivia (118), Nicaragua (124), Guatemala (125), Guyana (127), Honduras (130) and Haiti (163) rank lower than Paraguay. See UNDP, Human Development Report 2016: Human Development for Everyone (UNDP 2016). At the same time, a report that took account of an important segment of 'chronic' poverty in Paraguay, regarded ethnicity as a factor connected to this form of poverty. See Renos Vakis, Jamele Rigolini and Leonardo Lucchetti, Left Behind: Chronic Poverty in Latin American and the Caribbean (World Bank 2016) 72.

35 In this respect, Canada for example addresses the specific needs of indigenous populations in a more comprehensive approach that involves community participation, see Public Health Agency of Canada, Toward Health Equity: Canadian Approaches to the Health Sector Role (Public Health Agency of Canada 2014) 15, 19.
} 
stigmatization. How sound is a legal theory that seeks to set things right for one of many groups experiencing the same problem?

Yet, the fact that the nature of the reparations does not differ from social benefits is not in itself a reason to dismiss the applicability of positive obligations deriving from the right to life. The applicability of positive obligations seems clearly justified in the example of the healthcare afforded to prison inmates or other cases where the State's action or inaction leads to the immediate or automatic obliteration of classical rights. ${ }^{36}$ Due to the intense proximity of the State in those cases, it is clear that the life of the prisoner depended solely on the actions and omissions of the State. Arguably, the greater the relationship of dependency between the State and the individual or individuals in question, the greater the scope for positive obligations derived from the right to life. ${ }^{37}$ This is because certain acts or omissions by the State can lead to the deprivation of life or to a situation where the applicant ends up being subjected to ill treatment. This means, however, that in order to determine the correct applicability of these positive obligations, the causal link between the action or inaction of the State and the violation must be particularly intense. ${ }^{38}$ Unless the case for positive obligations emanating from the right to life is made under exceptionally restricted circumstances, such a legal doctrine would run the risk of depleting the sphere of involvement of the related social rights. The difficulty seems to lie in establishing the demarcation line between positive obligations deriving from individual rights and social rights. One possible point of orientation is that whenever the reparations suitable for the damage are not different from the welfare policies through which social rights are generally fulfilled, there is a strong indication that individual rights may be ill suited for dealing with those challenges.

As a result of the privations detected in Sawhoyamaxa (lack of access to healthcare, water, sanitary installations and food) the Court began by recognizing that the State was faced with different operative choices, multiple priorities

36 See Section 2.1.1 above.

37 This is to the extent of reversing the burden of proof in detention cases where death or injury occurs. For example, in the Salman case, the ECtHR established that "where the events at issue lie wholly, or to a large degree, within the exclusive knowledge of the authorities, as in the case of persons within their control in custody, strong presumptions of fact will arise in respect of injuries and death occurring during such detention. Indeed, the burden of proof may be regarded as resting on the authorities to provide a satisfactory and convincing explanation'. Salman v Turkey [2000] ECHR 357, (2002) 34 EHRR 17, para 100; see also Alexandra Timmer, 'A Quiet Revolution: Vulnerability in the European Court of Human Rights' in Martha Fineman and Anna Grear (eds), Vulnerability: Reflections on a New Ethical Foundation for Law and Politics (Ashgate 2013) 154.

38 Timmer, ibid. 
and limited resources to carry out its duties. ${ }^{39}$ Although not expressly admitted, those circumstances perfectly fit what has usually been considered the background to social rights, where multiple needs meet limited resources. Although the Court cited the right to health and other social rights, ${ }^{40}$ its reference to them seemed only metaphorical as the Court did not invoke social rights as the legal argument triggering its decision. As a matter of fact, the standard view of the Court at the time of these judgments was that, except for the right to unionization and the right to education, social and economic rights like the right to health or the right to food did not have direct applicability under the Inter-American System. ${ }^{41}$ As I comment further on, this view has changed in recent times.

Admittedly, the Court's judgment did contribute to significantly revealing an otherwise far less noticeable everyday social tragedy. This was seemingly the only available legal avenue for the Court to address the situation of these extremely deprived communities. Yet, if I cast criticism on this indirect trend, it is not on the grounds of theoretical coherence only, but is motivated by the idea that solidarity involves not only a theoretically sounder understanding of social rights but also, the possibility of a more just and efficient practical result.

\subsection{A Direct Individual Protection}

\subsubsection{The human dignity standard}

As a legal standard applied by courts, human dignity is a recurrent interpretative tool used in the context of the right to life and other individual rights. Two examples of the ways this standard has been used in the context of the right to health are provided in the Meza García case, before Peru's Constitutional Court, and Case T-737/11 before the Colombian Constitutional Court.

39 Sawhoyamaxa (n 26) para 155.

40 eg, Sawhoyamaxa (n 26) para 163.

41 Oswaldo-Rafael Ruiz-Chiriboga, 'The American Convention and the Protocol of San Salvador: Two Intertwined Treaties. Non-Enforceability of Economic, Social and Cultural Rights in the Inter-American System' (2013) 31(2) Netherlands Quarterly of Human Rights 159; Francesco Seatzu and Amaya Ubeda de Torres, 'The Social Charter of the OAS: A Step Forward in the Enforcement of Socio-Economic Rights in the Americas' (2014) 32(2) Netherlands Quarterly of Human Rights 130, 146; the abovementioned rights are enshrined in the Additional Protocol to the American Convention on Human Rights in the area of Economic, Social and Cultural Rights (Protocol of San Salvador) (entered into force 16 November 1999) OAS Treaty Series $N^{\circ} 69$ (1988) reprinted in Basic Documents Pertaining to Human Rights in the Inter-American System OEA/Ser L V/II.82 Doc 6 Rev 1 at 67 (1992), art 10. 
In Meza Garcia, the Court conceded the claim of the applicant - a woman who, living in extreme poverty and infected with HIV, claimed that her rights to life and health had been violated. The Court granted an antiretroviral treatment to combat her HIV infection. In short, the Court's reasoning was that not granting such a treatment would represent a constitutional omission on the part of the State. ${ }^{42}$ The State would in this case be obliged to act in defence of the right to health of the applicant, and its inaction would involve an infringement of the applicant's right to life. Given the applicant's situation of economic deprivation together with the health-related implications of HIV, the Court concluded that the applicant would be impeded from undergoing the illness with dignity. ${ }^{43} \mathrm{HIV} / \mathrm{AIDS}$ severely limits the exercise of autonomy when there is no possibility to access adequate treatment. As the Court stated in this case, HIV/AIDS also has the potential of affecting the psychology and the social relations of the person; in many cases the person effectively being reduced to the status of a 'social pariah' ${ }^{44}$ The Court's decision rests on the effects of a grave illness that together with the applicant's position of vulnerability makes her situation critical. Hence, the Court established that the applicant deserved 'integral treatment', which required the 'provision of the totality of the medical requirements (examinations, medicines) with the purpose of overcoming the illnesses' consequences'. ${ }^{45}$

Similarly, in Case T-737/11, ${ }^{46}$ filed before Colombia's Constitutional Court, protection was granted to Mr Luís Fernando Figueroa Ruiz, an indigent 40 -year-old male who was affected by multiple brain strokes and in chronic need of psychoactive drugs. The Court addressed the conditions of poverty and indigence of the claimant. It stated in this respect that poverty:

[T]hreatens the effectiveness of fundamental rights. Its structural causes are to be combatted through legislative and macro-economic policies. Its effects, instead, demand a direct immediate State intervention which is grounded on the social nature of the State and the effectiveness of the principles, rights and duties enshrined in the Constitution. ${ }^{47}$

\footnotetext{
42 Azanca Alheli Meza Garcia, Exp no 2945-2003-AA/TC, para 39 (Peru's Constitutional Court) (Meza García).

43 Meza García (n 42) para 22.

44 ibid.

45 ibid para 48.

46 Case T-737/11 Olivia de Jesús Ruiz de Figueroa (2011) (Colombia's Constitutional Court).

47 ibid para 2(4).
} 
The Court argued that in these cases, where the situation of people with disabilities, minors and old people was at stake, medical care could become fundamental in protecting human dignity. ${ }^{48}$

These two cases assessed the vulnerability of the applicants based on their medical and social conditions. They looked at the legal problem from the perspective of how these conditions limited the applicant's personal enjoyment of their fundamental rights, and although a connection with the right to health was made, the tribunals relied heavily on the notion of human dignity as the critical factor triggering legal protection.

In the T-737/11 case, the Colombian Constitutional Court recognized the effects of poverty. Just like in Meza Garcia, the argument in T-737/11 was that medical treatment for persons who have had brain strokes was crucial to a person's individual integrity. This, according to the Court, resulted in the granting of an integral protection to the affected individual.

While admittedly the HIV/AIDS pandemics have been the focus of the right to health and public health in the last two decades, the focus of the abovementioned judgments did not explicitly take those developments as a starting point. The assessment in these cases was exclusively based on the individual's circumstances. In the T-737/11 case, poverty is acknowledged, but only to the extent that it affects the claimant. After the Court's reflections on poverty and its decision to act upon it, one ends up with the impression that poverty is a somewhat unusual phenomenon in Colombia. One ends up wondering whether the same assessment could not have been used to arrive at the exact same conclusion - full integral protection - not just in all cases involving HIV or brain strokes, but also in a longer list of other grave health threats presently affecting these two countries. ${ }^{49}$

This apparently sudden realization of the gravity of HIV and cerebrovascular diseases is striking. Long before these judgments, countries such as Peru and Colombia had been suffering from these and other health threats, including what the WHO calls 'infectious diseases of poverty'.$^{50}$ This, obviously, occurs

\footnotetext{
48 ibid paras 2(1), 2(2).
}

49 In the case of Colombia, the top causes of death for both sexes in adults (30-64 years old) for the period 2007-2009 and 1997-1999 were ischemic heart disease and cerebrovascular diseases. In the case of Peru, acute respiratory infections, ischemic heart disease and cerebrovascular diseases occupied the first positions of leading causes of death for the year 2007. WHO and Pan-American Health Organization (PAHO), Health in the Americas (2009) (WHO and PAHO 2009) 527, 528.

50 Both Peru and Colombia have high morbidity on major infectious diseases which include bacterial diarrhoea, malaria, the zika virus and yellow fever. At the same time, both Peru and Colombia's population are also affected by five other diseases which are included in a WHO list of the main neglected tropical diseases worldwide, also called 'infectious diseases of poverty'. These are rabies, schistosomiasis, leishmania- 
when people live in extreme poverty, a percentage which actually remains high for both countries. ${ }^{51}$ Should it be regarded as a sound reflection whether poverty and indigence affect someone's life?

If one takes the reasoning of the Court to the letter, a right-to-life rationale based on human dignity would advise full healthcare coverage for a very long list of treatments to all persons in all circumstances. Framing these social problems from the perspective of individual human dignity involves an essentialist all-or-nothing approach, namely, that the only way of restoring the threatened dignity consists of granting the claimed protection. ${ }^{52}$

It is certainly disingenuous to expect that an individualized approach will seriously deal with an issue experienced by so many. This would require entirely restructuring the budget priorities of these States, something that did not occur after these judgments. Despite some progress, Colombia, Peru, but also India, still register high levels of poverty. Priorities need to be established not only within health interventions themselves, but also in considering other rights that are highly dependent on the State's social budget. In T-165/95, the Colombian Constitutional Court granted the claim requested by a girl suffering from leukaemia. ${ }^{53}$ Reasoning from the perspective of human dignity, the Court ordered the public system to finance the girl's treatment in a specialized clinic in the US. Besides funding for the entire medical treatment, the judgment included paying for the girl's plane ticket and one of her parents on the grounds of the right to life. ${ }^{54}$

While admittedly the courts addressed the principle of solidarity, their way of doing so did not lead to institutions that would systematically protect social

sis, African trypanosomiasis and dengue fever. See WHO, 'Global Report for Research on Infectious Diseases on Poverty' (WHO 2012) 13; Indexmundi, 'Peru Major Infectious Diseases' $<$ https://www.indexmundi.com/peru/major_infectious_diseases .html $>$ accessed 4 February 2021; Indexmundi, 'Colombia Major Infectious Diseases' $<$ https://www.indexmundi.com/colombia/major_infectious_diseases.html $>$ accessed 4 February 2021.

51 According to a study of the World Bank, in 2004 (the year of the judgment analysed was 2003) 'just over half of Peru's population was poor and about 20 per cent were extremely poor'. The same study indicates that 'Peru's poverty levels are below those of Ecuador and Colombia', see World Bank, 'Peru. Opportunities for All: Peru Poverty Assessment' (December 2005) Report N²9825-PE, 1; in 2015 poverty in Peru reached $21.8 \%$ of the population, World Bank, 'Poverty Headcount Ratio at National Poverty Lines (\% of the Population)' $<$ http://databank.worldbank.org/data/reports.aspx ? source $=2 \&$ type $=$ metadata\&series $=$ SI.POV.NAHC\# $>$ accessed 4 February 2021 .

52 Octavio Ferraz, 'Harming the Poor Through Social Rights Litigation: Lessons from Brazil' (2011) 89(7) Texas Law Review 1643, 1659.

53 T-165/95 Carolina Urina Jassir (19 April 1995) (Colombia's Constitutional Court).

54 ibid III(2). 
rights. The reference served to simply justify a duty towards 'the vulnerable', the same duty which should automatically trigger State action as otherwise the State would violate human dignity. ${ }^{55}$

This analysis should not be understood to mean that human dignity is an altogether wrong legal approach or that it has no link with these social issues. The question is: to what extent does the approach of human dignity suit the context of multifaceted and opposed needs describing the background of scarce resources where the right to health operates? These issues, which have also been referred to as 'polycentric problems' ${ }^{56}$ reflect the great dilemma posed by social rights: while an exclusive focus on (individual) human dignity may protect vulnerable subjects here and there, it may also lead to the denial of the human dignity of many others.

Similar dilemmas can be observed in cases that have more explicitly linked individual human dignity to the right to health, considered as an autonomous constitutional right. In this understanding, whenever medical attention is not made available, the right to health is regarded as having been infringed. ${ }^{57}$ This view has gained traction. Regarded as an absolute understanding of the right to health, it has been applied in countries like Brazil. ${ }^{58}$ Not only have the weakest not benefitted from that approach, ${ }^{59}$ the economic sustainability of the healthcare system has also been put at risk. ${ }^{60}$ Rather than focusing on the universal and egalitarian supply of the provision, the accent of these approaches is put on demand, ie the medical treatments required by the individuals who succeed

\footnotetext{
55 Meza García (n 42) paras 16, 24; T-737/11 (n 46) para 2(3).

56 See Section 3.1 below.

57 Ferraz (n 52) 1659-60.

58 ibid; also referred to as 'syllogistic' reasoning, see Mariana Mota Prado, 'The Debatable Role of Courts in Brazil's Health Care System: Does Litigation Harm or Help?' (2013) 41(1) Journal of Law, Medicine and Ethics 124, 130.

59 Carlos Portugal Gouvêa, 'Social Rights Against the Poor' (2013) 7(4) ICL Journal 454; Daniel Liang Wang and Octavio Motta Ferraz, 'Reaching Out to the Needy? Access to Justice and Public Attorneys' Role in Right to Health Litigation in the City of São Paulo' (2013) 18 Sur - International Journal on Human Rights 159; Jacob Mchangama and Christian Bjørnskov, 'Do Social Rights Affect Social Outcomes?' (2013) Aarhus University Economic Working Papers 18/2013, $18<\mathrm{http} / /$ econ.au.dk/fileadmin/site_files/filer_oekonomi/Working_Papers/Economics/2013/ wp13_18.pdf $>$ accessed 4 February 2021; Octavio Ferraz and Fabiola Vieira 'Direito à Saúde, Recursos Escassos e Equidade: Os Riscos da Interpretação Judicial Dominante' (2009) 52(1) DADOS - Revista de Ciências Sociais Rio de Janeiro 223, 225; Ludovic Reveiz and others, 'Litigios por Derecho a la Salud en Tres Países de América Latina: Revisión Sistemática de la Literatura' (2013) 33(3) Revista Panamericana de Salud Pública 213, 220.
}

60 Portugal Gouvêa (n 59) 463; Liang Wang (n 59) 165. 
in bringing their complaint to court. ${ }^{61}$ However, maintaining or extending the life of those who succeed in court does not necessarily lead to more egalitarian access to healthcare; it can in fact lead to the opposite. The practical ineffectiveness of these approaches is clear from the failure of the vertical healthcare strategies pursued from the 1990s. ${ }^{62}$

These results are inefficient, but they also threaten legal certainty because they fail to answer what happens with the dignity of those that are hit by structural sources of deprivation, when a similar absolute approach cannot be universalized. Furthermore, the abovementioned cases demonstrate that an excessive focus on the individual could lead to understandings where the right to health leads to medicalized adjudications, which could possibly damage the integrity and financial sustainability of healthcare systems.

\subsubsection{Further limitations of dignity and the individualistic rights language}

A common difficulty for Spanish speakers learning the English language lies in the so-called 'false friends' error, ie thinking that a word written in a similar way has the same meaning in the other language. Sometimes the meaning is the correct one, but that is not always the case. For example, the English word 'realize' means to become aware of something. Yet, the Spanish speaking student could be likely to think that the word refers to: realizar, which means carry out something.

Could it be that something that is regarded as so self-evident - like the fact that a legal right to health naturally leads to health equity - may actually turn out not to lead to that result in practice? Could the rights discourse be premised on 'false friends' in the sense that far from leading to health equity, they could actually be helping to advance the market in the healthcare sector? Paradigmatically, an excessive focus on human dignity, rather than protecting the dignity of all, may also be compatible with the persistence of structural disparities in access to healthcare. While here and there exemplary cases of vulnerability may acquire legal protection, the focus on human dignity may also lead to limiting State protection only to these exemplary cases, while structural rules of access remain unequal. While in those particular cases the unequal provision of the market is corrected and (at best) an entire group of individuals receives protection, the commercial provision of healthcare also becomes normalized. As discussed earlier, the interplay between human rights

61 This is irrespective of whether more collective remedies can limit this tendency, an argument put forward by Langford (Langford, Justiciability (n 8) 37). Yet, if the point is that collective remedies can ameliorate that process, that argument accepts the inherent importance of the generality of the standard.

62 Joseph Stiglitz, The Price of Inequality (Penguin Books 2013) 220. 
law and the market has been taken to such a level that the very lack of market attention may play a role in distinguishing the cases that should fall under the scope of the right to health. ${ }^{63}$

A case reflecting these kinds of dynamics is Chaoulli, ruled on by the Canadian Supreme Court. ${ }^{64}$ In Chaoulli, a majority established that Quebec laws (section 11 of the Hospital Insurance Act and section 15 of the Health Insurance Act) prohibiting private health insurance for medical services were unconstitutional. The Court judged this prohibition to be in violation of the rights to life and security under section 7 of the Canadian Charter of Rights and Freedoms and section 1 of the Quebec Charter of Human Rights and Freedoms.

The appellants were Mr Chaoulli, a surgeon who complained about the prohibition to provide medical services in the private sector, and Mr Zeliotis, who was affected by long waiting lists while in need of hip surgery. Mr Zeliotis argued that the prohibition infringed Quebeckers' right to life, as some patients died as a result of waiting for treatment in the public system when they could have gained prompt access to care in the private sector. ${ }^{65}$ The majority ruled that while the goals of the Quebec laws entailed a substantial objective - preserving the integrity of the public healthcare system by promoting healthcare of the highest possible quality for all Quebeckers regardless of their ability to pay - there was a wider range of measures that were less drastic, and also less intrusive than the absolute prohibition of private insurance. ${ }^{66}$ Furthermore, by comparing the healthcare systems of other Canadian provinces and other Organization for Economic Cooperation and Development countries, the majority concluded that even if the prohibition of insurance contracts was instrumental in preserving the public system's integrity, measures other than the prohibition could have had a similar effect. ${ }^{67}$

Moreover, the majority argued that the two guiding principles for paying deference to the legislature - the measures' consistency with democratic values and the necessity to maintain public order and the general well-being of citizens ${ }^{68}$ - did not apply in the case at hand, as the Government could not choose to adopt measures in violation of right to security of Quebeckers. ${ }^{69}$ Moreover, the effectiveness of the prohibition in ensuring its goals was not

\footnotetext{
$63 \operatorname{ch~4,~s~} 3.4$.

${ }^{64}$ Chaoulliv Quebec (AG) 2005 SCC 35, [2005] 1 SCR 791 (Supreme Court of Canada) (Chaoulli).

${ }_{65}$ Chaoulliv Quebec (n 64) Deschamps J, para 37.

66 ibid paras 49, 55, 83.

67 Chaoulliv Quebec (n 64) Deschamps J, para 74.

68 ibid para 93.

69 ibid para 97.
} 
considered proven. ${ }^{70}$ Lack of timely healthcare, the majority argued, could threaten life and the psychological security of the person and thus violate section 7 on the security of the person. ${ }^{71}$

It is interesting to note the dissenters' arguments, put forward by Justices Binnie and LeBel. These judges considered the purpose of the Canada Health Act and its provincial counterparts to be the provision of healthcare based on need rather than on wealth or status. ${ }^{72}$ While not all Canadian provinces prohibited private health insurance, almost all of them took steps to protect the public health system and discourage the private sector either by prohibiting private insurance, by prohibiting doctors who opt out of the public sector from billing their private patients more than in the public sector tariff, or by eliminating any form of cross-subsidy from the public to the private sector. ${ }^{73}$ In their view, the difficulties in the implementation of this policy arose from a complex fact-laden policy debate, which did not fit easily within the institutional competence of courts of law..$^{74}$ Moreover, they questioned whether the establishment of a single or a two-tier healthcare system was a matter on which courts of law were called to decide. ${ }^{75}$

The dissenters argued that 'the appellants' case did not rest on constitutional law, but on their disagreement with the Quebec government on aspects of its social policy. The proper forum to determine the social policy of Quebec in this matter was the National Assembly. ${ }^{76}$ For the dissenting judges, the equity and fairness of the policy came from the fact that the beneficiaries of the constitutional challenge would be 'Quebeckers who [had] the money to afford private medical insurance and [could] qualify for it', and not those Quebeckers 'who [did] not have the money to afford private health insurance, who [could not] qualify for it, or who [were] not employed by establishments that provided it'..$^{77}$

Regarding the arbitrariness that the majority found on the prohibition, the dissenters stated that this argument was based:

$[\mathrm{O}] \mathrm{n}$ generalizations about the public system drawn from fragmentary experience, an overly optimistic view of the benefits offered by private health insurance, an oversimplified view of the adverse effects on the public health system of permitting private sector health services to flourish and an overly interventionist view of the

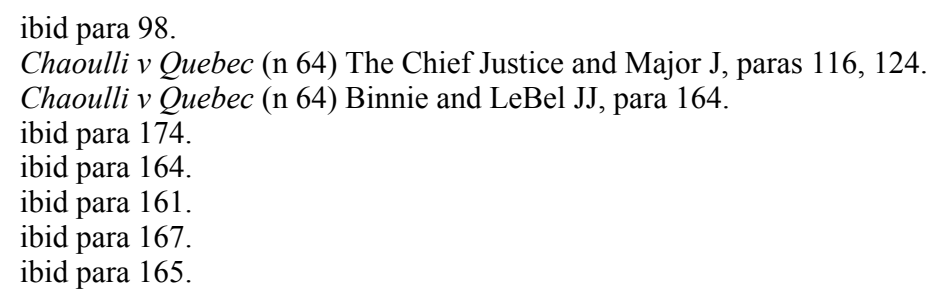


role the courts should play to supply a 'fix' to the failings, real or perceived, of major social programs. ${ }^{78}$

The dissenters also referred to the values behind the Canadian healthcare legislation. Reflecting on the question of who should be allowed to jump the queue, their answer was that:

[I]n a public system founded on the values of equity, solidarity and collective responsibility, rationing occurs on the basis of clinical need rather than wealth and social status. ... Patients who are in greater need of health care are prioritized and treated before those with a lesser need.... There are of course exceptions, and these exceptions are properly the focus of controversy, but in our view they can and should be addressed on a case-by-case basis. ${ }^{79}$

Concerning the evidence from other countries, the dissenters stated that that situation had already been assessed in interim report recommendations - the Kirby and the Romanow Reports - which had suggested keeping a single-tier system..$^{80}$ One of the considerations in these reports was an economic one. The Canadian Health Care System was ranked as one of the most efficient in terms of the ratio of productivity to administrative costs in the world. ${ }^{81}$

Reflecting on the decision, Aeyal Gross argues that the Chaoulli case shows how 'the idea of access was interpreted in a way that actually reinforces the relationship between wealth and healthcare, opening the door to a system where the determining factor will not be need but rather the ability to pay for private health insurance' ${ }^{82}$ In this constellation, the case appears to be a warning of how 'introducing human rights to the area of public health care may be used not to expand equality, but rather to re-articulate claims to private health care as human rights claims' ${ }^{83}$

In commenting on the decision, Jeff King stated that:

$[\mathrm{T}]$ he Charter privileged a right to security of the person over the competing interest of providing effective and efficient public health care to those who cannot afford private insurance. The majority found, as have English courts in a similar context, that there is no freestanding right to health care. Thus the richer patient's right to buy private insurance trumps the poorer person's mere policy interest in being provided with high quality medical care. ... Had the constitution recognised a right to health

ibid para 169.

ibid para 223.

ibid paras 226, 230.

ibid para 252.

Aeyal Gross, 'Is There a Human Right to Private Health Care?' (2013) 41(1) The

Journal of Law, Medicine and Ethics 138, 140.

83 ibid 143. 
care with positive dimensions, the majority would have had to confront rather than ignore this conflict of rights. ${ }^{84}$

While King's suggestion of a right to health included in the Bill of Rights would entail a step forwards for the right to health, the difficult road towards health equity and social justice cannot be fully explained by a simple lack of constitutional eloquence. In my view, the real difficulty lies in the conditions under which social rights have been welcomed in our legal culture.

As Fernando Atria notes, Western legal systems are largely based on the Dworkinian distinction between arguments of principle and arguments of politics. ${ }^{85}$ Arguments of politics successfully justify any decision as long as they do not clash with arguments of principle. Arguments of principle are those referred to in the most fundamental questions about political morality ${ }^{86}$ (where one would expect to find basic notions of civil and political rights). Unlike arguments of principle, arguments of politics are not correct or incorrect. They just need to be adopted in accordance with pre-established procedures such as, for example, the required legislative quorum. Arguments of politics only reflect citizens' opinions. For this reason, they need to be aggregated; those accumulating a greater number of preferences become adopted on behalf of the community.

The prohibitions on private insurance and private healthcare provision reflect a way of protecting the healthcare system's integrity as reasoned by the dissenters in Chaoulli. Taking Dworkin's view on these issues, they would not be arguments of principle since they do not engage any fundamental question of political morality. Something different occurs in regard to the individual rights the majority protected in Chaoulli. Those rights do entertain fundamental questions of political morality and are therefore not reducible to transactions, to the extent that their protection justifies striking down prohibitions that resulted in a healthcare system which, according to specialized medical reports cited in the case, was one of the most efficient in the world. ${ }^{87}$

Agreeing with what Jeff King suggests, I also believe that a great deal of improvement on the side of the right to health can be gained from its constitutional inclusion. Yet, I do not think that that is the only or even the major challenge at stake, since many countries with non-solidary access to healthcare

${ }^{84}$ Jeff King, 'Constitutional Rights and Social Welfare: A Comment on the Canadian Chaoulli Health Care Decision' (2006) 69(4) The Modern Law Review 619, 639.

85 Fernando Atria, La Forma del Derecho (Marcial Pons 2016) 304.

86 ibid.

$87 \quad$ See $n 81$. 
already have those provisions. ${ }^{88}$ In my view the challenge is whether the right to health - understood not as an individual legal right, but in line with solidarity - can ever become protected on an equal footing together with the select group of the fundamental questions defining 'our' political morality.

Not much of that has been seen so far. One even wonders to what extent the right to health became palatable in Western legal culture precisely because of its operationalization as an individual legal right, ie a formal entitlement unable to question healthcare commercialization. Yet, could the right to health overcome this difficulty, and be envisioned as a non-marketed right, as presented in the second half of chapter four?

Developments such as those outlined in Chaoulli are a stark reminder of the predominant interpretation's unclear contribution to public health and health equity. This should not lead to abandoning the cause of the right to health, but to a quest to identify what means could deliver these goals.

\subsubsection{Recent direct inter-American jurisprudence}

The Inter-American Court of Human Rights recently inaugurated a direct and autonomous protection of social rights and abandoned the indirect practice of protecting social rights by virtue of positive obligations derived from civil rights, such as the right to life and physical integrity. The main contributor to this development was Judge Eduardo Ferrer, the current President of the Court who, in a dissenting opinion in the Suárez Peralta $v$ Ecuador case, ${ }^{89}$ expressly called on the Court to move in this direction. The Inter-American Court followed suit: in the Poblete Vilches and others $v$ Chile case, ${ }^{90}$ for the first time it adopted this perspective in declaring that the State had directly violated the right to health. ${ }^{91}$

The provision by virtue of which the Inter-American Court has found itself to be competent to adjudicate these social rights has been Article 26 of the American Convention. ${ }^{92}$ As mentioned earlier, this provision has been the

88 At least 'in 63 countries, the constitution, bill of rights, or other statute recognize the right to health', see Gunilla Backman and others, 'Health Systems and the Right to Health: An Assessment of 194 Countries' (2008) 372 The Lancet 2047, 2075.

89 Suárez Peralta v Ecuador (Preliminary Objections, Merits, Reparations and Costs) Inter-American Court of Human Rights, 21 May 2013.

90 Poblete Vilches and others $v$ Chile (Merits, Reparations and Costs) Inter-American Court of Human Rights, 8 March 2018.

91 ibid para 176.

92 'Article 26. Progressive development. The States Parties undertake to adopt measures, both internally and through international cooperation, especially those of an economic and technical nature, with a view to achieving progressively, by legislation or other appropriate means, the full realization of the rights implicit in the economic, social, educational, scientific, and cultural standards set forth in the Charter of 
focus of intense discussion..$^{93}$ Whether the Court, in its interpretation of the American Convention, was or was not entitled to go beyond civil and political rights and adjudicate on economic, social and cultural rights is not the goal of this analysis. I am only interested in the way in which this was done.

\subsubsection{Judge Ferrer's concurring opinion in Suárez Peralta v Ecuador}

This concurring opinion is important as the Court confirmed most of its rationale subsequently in the Poblete Vilches case. I will therefore reconstruct the considerations that led Judge Ferrer to seek the direct adjudication of social rights. ${ }^{94}$ For a start, Judge Ferrer sees interdependency and indivisibility as an 'inseparable binomial category'. ${ }^{95}$ Interdependency would entail 'reciprocal dependency' between the various human rights, ${ }^{96}$ and indivisibility would 'deny any separation, categorization or hierarchy between rights for the effects of their respect, protection and guarantee'. ${ }^{97}$ According to Judge Ferrer these two concepts are important as they help to disentangle social rights' 'own characteristics' ${ }^{98}$ As a corollary of this view, these rights can be 'autonomously violated'. ${ }^{99}$

Moreover, Judge Ferrer is concerned that the indirect case law of the Court may risk failing to identify social rights in its essential or specific features. ${ }^{100}$ Furthermore, in a relatable interrogation, Judge Ferrer discusses the implications that could be derived from the progressivity of social rights. ${ }^{101}$ In clarifying this progressivity, he thinks that retrogression should be opposed..$^{102}$ Yet, complementing this starting point, he makes a comparative assessment of domestic right-to-health jurisprudence in the Americas. Certain ideas in this regard are no doubt important, for example the assessment of the merits and criteria to organize waiting lists in Costa Rica, ${ }^{103}$ or the enforcement of a list

the Organization of American States as amended by the Protocol of Buenos Aires.' American Convention on Human Rights, 'Pact of San Jose', Costa Rica, 22 November 1969 (Organization of American States (OAS)) art 26.

93 See $\mathrm{n} 41$.

94 Given that both Judge Ferrer's opinion in the Suárez Peralta case as well as the judgment of the Poblete Vilches case are only available in Spanish, my references to both are based on my own translations from this language.

95 Suárez Peralta $v$ Ecuador case, reasoned vote of Judge Eduardo Ferrer, Inter-American Court of Human Rights, para 25.

96 ibid para 24.

97 ibid.

98 ibid para 27.

99 ibid.

100 ibid paras 57, 101, 103.

101 ibid para 58.

102 ibid para 71.

103 ibid para 82. 
of basic medicines in Mexico. ${ }^{104}$ Other developments are in my view less original and are unnecessary for the construction of autonomous right-to-health jurisprudence. For example, the understanding of the notion of solidarity in Colombian case law, ${ }^{105}$ which is operationalized as a way to emphasize the need to protect vulnerable individuals and to reinforce individual justiciability in courts of law. ${ }^{106}$ What is definitely less felicitous is Judge Ferrer's praise for certain judicial developments in Canada. ${ }^{107}$ As discussed earlier, if anything, these developments have made healthcare more commercial. ${ }^{108}$ And the commercialization of healthcare, as pointed out in the previous chapter, limits access to healthcare on an egalitarian basis. ${ }^{109}$ Finally, some elements considered important for an autonomous right to health are further highlighted: the duty to effectively regulate healthcare services (either public or private) ${ }^{110}$ and the connection between the right to health and the need to avoid medical malpractice. ${ }^{111}$

\subsubsection{The Poblete Vilches and Others v Chile case}

In this case concerning medical malpractice, the Court concluded that several standards derived from the right to health were applicable in the area of healthcare provision in situations of emergency. ${ }^{112}$ The Court considered that the applicable standard of the right to health concerned access to essential healthcare services, the guarantee of effective and high quality medical care, and the duty to improve the general conditions of health for the population. ${ }^{113}$ The operationalization of these obligations requires a 'duty to regulate' services, whether public or private in nature, as well as to execute national programmes seeking to provide good quality services. ${ }^{14}$

In operationalizing the topic of accessibility, the Court heavily relied on UN guidelines, more specifically General Comment 14 and the AAAQ standard

104 ibid para 84.

105 ibid para 77.

106 Suárez Peralta v Ecuador, Ferrer (n 95) paras 77, 80, 87; for my critique see ch 4, s 3.1 .

107 ibid para 85.

108 See Section 2.2.2.

109 ch 4, n 91.

110 Suárez Peralta v Ecuador, Ferrer (n 95) para 90; this contribution can be traced back to the Ximenes Lopes case (Ximenes Lopes v Brazil (Merits, Reparations and Costs), Inter-American Court of Human Rights, 4 July 2006, para 146).

111 Suárez Peralta v Ecuador, Ferrer (n 95) paras 91, 94.

112 Poblete Vilches n 90, para 116.

113 ibid para 118.

114 ibid para 119. 
(availability, accessibility, acceptability and quality). ${ }^{115}$ In developing the condition of accessibility, the Court recounted that this access should be provided without discrimination, including economic position, birth or any other social condition. ${ }^{116}$ According to the Court, accessibility consisted of an obligation to guarantee the prohibition of discrimination in both its negative and positive dimensions. ${ }^{117}$ Furthermore, based on conclusions from the Suárez Peralta case, the Court concluded that with regard to the supervision in the provision of services of public interest, responsibility could emerge from omissions in the duty to supervise. ${ }^{118}$ To illustrate these omissions, the Court provided the following examples: 'the granting of medical attention in institutions lacking the required equipment in terms of infrastructure or hygiene, or [the provision of treatments] given by professionals that are not qualified for the activities performed; all of which could endanger the rights to life or the integrity of the patient'. ${ }^{119}$

Furthermore, the Court also considered the age of the patient as a reason for his denial of treatment and assessed it from the perspective of the duty of non-discrimination. The Court concluded that an even greater duty existed with respect to elderly people. ${ }^{120}$ Finally, the Court took issue with the lack of consent of the patient and his family members as well as the further falsification of this consent by hospital personnel. Even though the issue was assessed in the context of the right to personal integrity, the Court linked this conclusion to the right to health. ${ }^{121}$

From the perspective of access to healthcare, the main way in which the question of access was addressed was by reinforcing the prohibition of discrimination. Yet, the specific contribution or added value of declaring a violation of the right to health remained unclear. Judging from the point of view of the prospects of finding a violation, the right to health did not appear to provide much added value in the sense of doing something that the general prohibition of discrimination would not have been able to do. By the same token, the assessment of the right to health was limited to a situation of emergency.

Jurisprudence that puts emphasis on the prohibition of discrimination and the duty to regulate healthcare services irrespective of their public or private nature in situations of medical emergency, does admittedly contribute to the construction of a system of health protection based on equality of oppor-

\footnotetext{
ibid para 120.

ibid para 122.

ibid para 123.

ibid para 124.

ibid para 124.

120 ibid paras $139,140$.

121 ibid paras $160,174-76$.
} 
tunity. ${ }^{122}$ To that extent, these focuses match the goal of the predominant interpretation of the right to health. Yet, as it was mentioned in chapter two, ${ }^{123}$ the predominant interpretation transmutes the right to the highest attainable standard of health into equal opportunity to that standard. As I will show in the next Section, a more faithful interpretation of this highest attainable standard does not collapse it into formal equality, but it understands it in line with health equity and solidarity.

As a result of the need identified to acknowledge the specificities of social rights, the efforts of Judge Ferrer and the Inter-American Court have gotten very close to the crux of social rights. That said, the inability of this focus to move beyond equality of opportunity makes all their efforts appear to be a reiteration of non-discrimination. The fact that their efforts of identification have not yet opened up room for grievances going beyond formal equality, means that this effort of identification has not yet been completed.

\section{ADJUDICATING THE RIGHT TO HEALTH ALONG WITH SOLIDARITY}

The previous Section assessed the prospects of attaining the goals of the right to health through individual rights either directly or through a collateral focus. In this Section, I refer to the prospects of protecting the right to health by directly enforcing this rights' constitutive components as defined in the second half of chapter four. I begin by describing the conundrum in which social rights are situated, otherwise called the polycentric challenge affecting modern courts of law.

My view is that unless one begins from a substantive definition of what social rights are, a quantitative and judicial approach on social rights (the amount of decisions on social rights adjudicated by courts of law) do not necessarily indicate whether these rights are being advanced. Langford, in his attempt to extend individual justiciability to social rights, ${ }^{124}$ is critical of President Nixon's administration due to the lack of judicial decisions on social rights. While there may be many reasons to be critical of that administration, ${ }^{125}$ I am not convinced that social rights is one of them. ${ }^{126}$ For Langford, it is

122 See $\mathrm{n} 15$.

123 ch $2, \mathrm{n} 104$.

124 Langford (n 61) 30-31, 43.

125 See ch 3, n 70.

126 Rutger Bregman, 'Nixon's Basic Income Plan: Why Richard Nixon Once Advocated for Basic Income - and Then Turned Against It', (5 May 2016 Jacobin) $<$ https://www.jacobinmag.com/2016/05/richard-nixon-ubi-basic-income-welfare/> accessed 4 February 2021. 
apparently irrelevant in relation to social rights that from 1945 to 1985 , the US enjoyed the lowest levels of income inequality in its entire history. ${ }^{127}$ Purely on jurisprudential developments, Langford deems the situation in Germany after 1972 as 'slightly more successful' for social rights. ${ }^{128} \mathrm{He}$ thinks that since the US, France and Ireland 'have frequently been hostile to social rights', these jurisdictions cannot be labelled as "predominantly "progressive". ${ }^{129}$

Langford's account, which avoids a substantive definition of social rights, appears close to a nominal understanding of social rights; a view disconnected from critical issues of social class and redistribution. These accounts have blurred the definition of what it is to be progressive in the protection of social rights. No wonder that today, as Colin Crouch has argued, it is the far right and its nationalism that successfully captures the redistributive emancipatory horizons that human rights have been abandoning. ${ }^{130}$ As set out in the second half of chapter four of this work, the right to health should not be operationalized in ways that give up economic perspectives of social justice.

\subsection{The Polycentric Challenge}

Courts have an uneasy relationship with social rights. These obstacles should not be viewed as a problem concerning mentality, where courts would be ideologically reluctant to protect the content of social rights. That may certainly be the case with respect to many judges, but it is not a problem that I am interested in tackling here. What I am concerned about are the institutional obstacles the collective nature of social rights poses for courts.

The modern understanding of the judiciary requires overcoming the old legal notion of justice being rendering to everyone his due (suum ius cuique tribuere).$^{131}$ It is hard to ask a judge, on the one hand, to apply the law if, on the other hand, he or she is requested to pay attention to distributive justice considerations. To some, the idea of solidarity may entail exactly that - a political claim incapable of being translated into a legally operational language.

To make matters even more difficult, letting courts decide on healthcare priorities is an effort that the scholar Lon Fuller would have been likely to

127 Thomas Piketty, Capital in the Twenty-First Century (HUP 2014) 24.

128 Langford (n 61) 6.

129 Langford (n 61) 4.

130 Colin Crouch, 'The Familiar Axes of Politics Are Changing, With Momentous Consequences' (Open Democracy, 23 September 2016) <https://www.opendemocracy .net/uk/colin-crouch/familiar-axes-of-politics-are-changing-with-momentous -consequences $>$ accessed 4 February 2021.

131 Fernando Atria, 'Réplica: Derecho y Política a Propósito de los Derechos Sociales' (2004) 4 Discusiones: Derechos Sociales 145, 169. 
regard as an example of an allocation problem for which adjudication would be 'utterly unsuited'. ${ }^{132}$ Fuller's statement concerned the dimension inherent to cases that could be described as 'many centred'. ${ }^{133}$ Jeff King, interpreting Fuller, states that 'a polycentric problem is one that comprises a large and complicated web of interdependent relationships, such that a change to one factor produces an incalculable series of changes to other factors'. ${ }^{134}$

Polycentric challenges seem particularly manifest in the adjudication of social rights. Here, any decision on right-to-health enfranchisements is likely to have repercussions for the extension of other enfranchisements linked to this right (not to mention other human rights). The problem seems to be related to the kind of 'demands' ${ }^{135}$ these rights involve. In the context of social rights, these demands are unlikely to satisfy the 'essential conditions' in which adjudication can be delivered. It is, for example, questionable whether judges, acting within the limited legal contours of their function, could ever overcome this difficulty, ie granting an entitlement that would not come at the expense of another entitlement. This is different from saying that social rights are too complex to be suited for judicial oversight; that would not be a good enough reason to renounce judicial monitoring. ${ }^{136}$ The point is not made on grounds of technical complexity, but on whether a court, by virtue of its institutional design, can even perceive the problems its decisions may generate. Arguably, the polycentric dimension can be present at several adjudicatory levels. Yet, Fuller's point did not consist of 'distinguishing black from white, [but it was] a question of knowing when the polycentric elements ... become so significant and predominant that the proper limits of adjudication have been reached'. ${ }^{137}$

As I show further on when considering the Soobramoney case, ${ }^{138}$ judges have reflected on this problem and have sometimes preferred to defer decisions to the legislature. The underlying reasoning is understandable. It is not that the legislature is better suited to eradicate the polycentric dilemma. On the contrary: it is the very fact that the problem cannot be eradicated which makes the political arena fit for the challenge. If the enforcement of an entitlement comes

132 Lon Fuller, 'The Form and Limits of Adjudication' (1978) 92 Harvard Law Review 353, 401.

133 ibid 395.

134 Jeff King, 'The Pervasiveness of Polycentricity' (2008) Public Law 101, 101-102.

135 Fuller (n 132) 363.

136 ICJ, Courts and the Legal Enforcement of Economic, Social and Cultural Rights: Comparative Experiences of Justiciability (ICJ 2008) 90.

137 Fuller (n 132) 398.

138 Soobramoney v Minister of Health, KwaZulu-Natal [1997] ZACC 17, (1997)

(12) BCLR 1696 (South Africa's Constitutional Court) (Soobramoney). Also see Nitecki (n 20). 
at the expense of sacrificing another entitlement, leaving the decision in the hands of the legislature provides at least political accountability.

In the following subsections, I will consider certain jurisprudential developments on this matter. To conclude, I will identify certain instances where the judiciary has met the challenge of contrasting the different criteria created by legislatures in a way that I regard consistent with the right to health informed by solidarity.

\subsection{South Africa}

\subsubsection{The Soobramoney case}

In this important case, the South African Constitutional Court came closer to adopting a methodological approach to social rights, namely, a collective or at least a non-individual understanding of these rights.

The applicant, Mr Thiagraj Soobramoney, was a man suffering from chronic renal disease. Prolonging his life was dependent on the application of regular renal dialysis treatment. Although the applicant had begun treatment at a private medical facility, he was unable to continue to pay for it and so he requested medical care from the Addington State Hospital in Durban. The applicant was refused treatment because, according to the hospital's guidelines, patients like the applicant, who suffered from chronic irreversible renal failure, or who were not eligible for a kidney transplant, were not automatically admitted to the renal programme. The guidelines favoured cases where there was a possibility of total recovery, and not just prolongation of the patient's life. The guidelines responded to the interests of a vast amount of people in search of such treatment at healthcare service providers that had few dialysis machines available, while at the same time were severely understaffed and underfinanced in terms of human and economic resources. The High Court of Kwazulu-Natal rejected the applicant's claim. The applicant thus brought an appeal at the Constitutional Court based on section 27(3) of the Constitution which provides that ' $[\mathrm{n}] \mathrm{o}$ one may be refused emergency medical treatment', and section 11, which provides that '[e]veryone has the right to life'. The Constitutional Court upheld the High Court's decision.

The Court's analysis took note of the non-individual nature of social rights. Unlike the Paraguayan cases, in Soobramoney, the Court never reduced the right to health to an individual or group problem. At the same time, the Court addressed the polycentric dilemma involved in the case: the hospital guidelines - from which the solidarity, integrity and financial sustainability of the healthcare system depended - were upheld. Thus, the decision appears to be a clear expression of social rights adjudication in the terms set out in the second half of chapter four. 
The story changes in relation to the way the Court interpreted the positive obligations deriving from the right to health. The judgment did not address the scope of the South African healthcare system, nor made any contrast between the private and the public sector. The Court limited the problem to the availability of dialysis treatment within the public healthcare sector. The judgment did not tackle the coexistence of different parallel regimes of access to healthcare within South Africa. Nor did it consider the fact that what made that parallelism possible was South African legislation. In that respect, access to healthcare was determined not by citizenship or medical need (prioritized, for example, based on quality-adjusted life years (QALYs) ${ }^{139}$ ), but merely on economic privilege - those with the ability to pay go to the private sector where they can purchase the services they need. For the upper classes of South Africa who, thanks to South African legislation, are able to access a private healthcare system responsive to their specific healthcare needs, the idea of scarcity in healthcare was unheard of. From the reading of Soobramoney one ends up with the impression that the jurisdiction of the Constitutional Court of South Africa to define what the right to health was about, is limited not to 'all renal clinics throughout the land', ${ }^{140}$ but only to those within the public healthcare sector.

Why was it not legally relevant that while Mr Soobramoney was not getting treatment due to understandable material constraints, other South Africans were obtaining exactly those treatments because of their economic privilege? Could not the Court, in line with solidarity, replace the legislation that granted commercialized healthcare by a more universalistic one? This could have been a possibility and the Constitutional Court could have contrasted the healthcare system with universal and free-access schemes in place for the white population during the times of the apartheid regime in the ambit of tertiary services and academic medicine (after deleting the obviously unconstitutionally racist aspects, that is).$^{141}$ The Court did not do any of this and it simply limited itself to being deferent to Parliament.

Further, in its $T A C$ judgment, the South African Constitutional Court adopted a standard that sought to justify when to step in and involve itself in these challenges. The TAC case draws upon the precedent set by the

139 WHO, Making Fair Choices on the Path to Universal Health Coverage: Final Report of the WHO Consultative Group on Equity and Universal Health Coverage (WHO 2014) 13.

140 Soobramoney (n 138) Chaskalson P, para 24.

141 Solomon Benatar, 'Health Care Reform in the New South Africa' (1997) 336(12)

The New England Journal of Medicine 891. 
Grootboom decision. ${ }^{142}$ Although Grootboom refers to a different fundamental right - the right to housing - TAC reproduces the same logic and the same legal standard (reasonability). For this reason, before dealing with the TAC case, I will first address the Grootboom decision.

\subsubsection{The Grootboom case}

In this case, South Africa's Constitutional Court kept its non-individualistic assessment concerning social rights. The case referred to the situation of Mrs Irene Grootboom, a person who lived with a group of people in a squatter settlement in extremely precarious conditions. The settlers experienced permanent flooding during the winter rains, severe overcrowding and perilous proximity to busy roads. After being effectively evicted and their few possessions destroyed, the settlers sheltered on the Wallacedene sports field. Mrs Grootboom filed an urgent application to the High Court. She claimed adequate basic temporary shelter or housing for the settlers and their children, pending their obtaining permanent accommodation. She also claimed basic nutrition, healthcare and social services for the respondents who were children.

The claim was based on two constitutional provisions - section $26^{143}$ and section 28(1)(c) ${ }^{144}$ of the Constitution. ${ }^{145}$ Going beyond the classic individual human dignity approach - whether individuals' needs were met - the Court referred to the way the challenged norms excluded the affected group. The issue to be decided, according to the Court, was 'whether the nationwide housing program [was] sufficiently flexible to respond to those in desperate need in our society and to cater appropriately for immediate and short-term requirements'. ${ }^{146}$ In other words, whether the absence of a component of the programme catering for those in desperate need could be regarded as 'reasonable'. ${ }^{147}$ The Court concluded that budgetary support by the national government had to be capable of 'meet[ing] immediate needs'. ${ }^{148}$ And also that

142 South Africa v Grootboom [2000] ZACC 14, 2001 (1) SA 46 (CC) (South Africa's Constitutional Court) (Grootboom).

143 'Section 26 Housing (1) Everyone has the right to have access to adequate housing. (2) The State must take reasonable legislative and other measures, within its available resources, to achieve the progressive realisation of this right. (3) No one may be evicted from their home, or have their home demolished, without an order of court made after considering all the relevant circumstances. No legislation may permit arbitrary evictions.'

144 'Section 28 Children. Every child has the right - ... (c) to basic nutrition, shelter, basic health care services and social services.'

145 Grootboom (n 142) Yacoob J, para 13.

146 ibid para 56.

147 ibid para 63.

148 ibid para 68. 
'[those in desperate need] are not to be ignored in the interests of an overall program focused on medium and long-term objectives'. ${ }^{149}$

Nonetheless, the Court did admit that the situation of the applicants was 'no worse than that of thousands of other people, including young children, who remained at Wallacedene'. ${ }^{150}$ The Court ordered the provision of 'relief for people who have no access to land, no roof over their heads, and who are living in intolerable conditions or crisis situations'. ${ }^{151}$

The standard inaugurated by the Court deserves some specific reflection.

South Africa's Constitutional Court's rejection of the doctrine of the minimum core as promoted by the Committee appears to be more realistic. As material conditions for the realization of social rights may not exist, a minimum core of these social rights is not assumed. ${ }^{152}$ Yet, the reasonability standard which was further developed in Grootboom is not exempt from challenges. What is really assessed when a court formulates a reasonability question? According to Ávila, reasonableness can be understood in relation to three notions: fairness, congruence and equivalence. In connection with fairness, Ávila states that according to Aristotle, fairness is 'a remedy for the law when and where it is deficient for being general'. ${ }^{153}$ In this respect, reasonability entails 'a tool to determine the factual circumstances that ought to be assumed as within normalcy'. ${ }^{154}$ Linked to congruence, reasonableness requires a correlation between 'criterion and measure'. ${ }^{155}$ Finally, reasonableness as equivalence, aims to a certain degree of 'proportionality' between the norm and its legal consequences. ${ }^{156}$

Ávila also emphasizes the importance of proportionality, which is a criterion different to reasonableness. Proportionality requires:

[T] hat the Legislative and the Executive choose appropriate, necessary and proportional means in order to achieve their purposes. A means is appropriate if it promotes the purpose. It is necessary if, among all other equally appropriate means to promote the purpose it is the least restrictive regarding fundamental rights. And it is proportional, in a narrow sense, if the advantages it promotes are superior to the disadvantages it causes. The application of proportionality requires the relation of

\footnotetext{
149 ibid para 66.

150 ibid para 81.

151 ibid para 99(2)(b).

152 Soobramoney (n 138) para 11; Minister of Health $v$ Treatment Action Campaign (TAC) [2002] ZACC 15, (2002) 5 SA 721, paras 34-35, 39 (South Africa's Constitutional Court) (TAC).

153 Humberto Ávila, Theory of Legal Principles (Springer 2007) 107.

154 ibid 106.

155 ibid 109.

156 ibid 110.
} 
causation between means and purpose so that the adoption of the means promotes the purpose. ${ }^{157}$

Thus, in a narrow sense the test of proportionality 'requires the comparison between the importance of realizing the end and the degree of restriction of the fundamental rights'. ${ }^{158}$

Western legal culture knows few ways of operationalization beyond the technique of individual legal rights. ${ }^{159}$ While the technique of legal rights is suited for conflicts arising between two individuals, it seems to get into difficulties when it comes to operationalizing communitarian legal claims. So far, as courts have worked under the purview of the predominant interpretation of the right to health, they do not see collective legal claims in social rights. The equality they care for is the equality of everyone not to experience the most abject deprivation. It does not include an equality of institutions or an 'equality of results', for cases in which economic or social privilege determines the quality of the institutions or the extent of the services everyone receives.

When the role of the legislature is limited to non-discrimination, human dignity, or reasonability, the question social rights tries to address, never really gets to be formulated. ${ }^{160}$ The question of the Grootboom case can be rephrased as follows: why do certain individuals get a level of X (in this case housing) that is below the standard of what we the judges regard as a minimum

157 ibid.

158 ibid 12; in a similar way, considering it a pure exercise of proportionality, Candia criticizes the so-called 'substantial' margin of appreciation in the context of the Council of Europe human rights system. See Gonzalo Candia, 'Comparing Diverse Approaches to the Margin of Appreciation: The Case of the European and the Inter-American Court of Human Rights' (9 March 2014), <https://ssrn.com/abstract $=2406705>$ accessed 4 February 2021, 9 .

159 Frankenberg has described this phenomenon as 'a reduction of the imaginative space of emancipation'. See Günter Frankenberg, 'Human Rights and the Belief in a Just World' (2014) 12(1) International Journal of Constitutional Law 35, 54.

${ }_{160}$ In the landmark case Broeks $v$ The Netherlands for example, the Human Rights Committee found that a widow who stopped being eligible for social security benefits did not fall under the right to social security of the ICESCR. The Committee found that the complainant was entitled to social security benefits by virtue of art 26 (non-discrimination). The Committee determined that the applicant had been discriminated against on the grounds of sex. Had she been a man, she would have been entitled to receive the invoked benefits. The Committee found that the case did not concern 'whether or not social security should be progressively established in the Netherlands, but whether the legislation providing for social security violates the prohibition against discrimination contained in Article 26 of the International Covenant on Civil and Political Rights'. Broeks $v$ the Netherlands Communication $\mathrm{N}^{\circ} 172 / 1984$, UN Doc $\mathrm{CCPR} / \mathrm{C} / \mathrm{OP} / 2$ at 196 (1990) paras 6(3), 12(5) (UNHRC). 
threshold for it to be compatible with human dignity? ${ }^{161}$ In asking this question, the Court involved itself in a substantive appraisal of justice, namely, what is above and below the standard of human dignity.

In this analysis, the judiciary contrasts differences of access within this most basic regime of access (the one that services the needs of those who depend on social assistance). What the judiciary does not do, however, is contrast the disparities between persons located in the greater regimes of access. And neither does it look at the reasons for such greater access being granted. Due to its connection to human dignity, reasonability appears to work only when challenging statutes that deal with the conditions of the poorest. This is done under the alleged neutrality of this standard, namely, the idea that because this view emerges from a 'reasonable' standard or because it focuses on the rights of 'the most vulnerable' or on a 'minimum core' of the right, it can claim political impartiality.

While the predominant interpretation presents its reliance on judicial adjudication and the reasonability standard as being impartial, this is in fact quite dubious. A strong affinity between the predominant interpretation of the right to health and the doctrine of liberal egalitarianism can be detected. For a start, it is disputable that meta-legal concepts can claim any impartiality. ${ }^{162}$ Despite its efforts to show the opposite, liberal egalitarianism is no exception. Take John Rawls's approach to justice. Such a view does not consist of directly defending the institutions favoured by the author (liberal democracy). Using the hypothetical tool of the veil of ignorance, Rawls arrives at his preferred result not offering reasons in its favour, but based on what he regards the choices rational people would adopt. ${ }^{163}$ Richard Bellamy and Chantal Mouffe have addressed the limitations of this approach. Bellamy criticizes Rawls's view as being 'too indeterminate' and 'circular - building its results into its premises' ${ }^{164}$ Mouffe fleshes out this criticism arguing that in Rawls's conception 'reasonable persons are persons "who have realized their two moral powers to a degree sufficient to be free and equal citizens in a constitutional regime, and who have an enduring desire to honour fair terms of cooperation and to be fully cooperating members of society"' ${ }^{165}$ Mouffe asks "What is this if not an indirect form of asserting that reasonable persons are those who accept the fundamentals of liberalism?'166 Further, she claims: 'What Rawls

\footnotetext{
161 Grootboom (n 142) para 44.

162 Atria, Forma (n 85) 321-22.

163 John Rawls, Political Liberalism (Columbia University Press 1993) 304-307.

164 Richard Bellamy, Political Constitutionalism: A Republican Defence of the Constitutionality of Democracy (CUP 2007) 185.

165 Chantal Mouffe, The Democratic Paradox (Verso 2009) 24.

166 ibid.
} 
is really indicating with such a distinction [reasonable/unreasonable] is that there cannot be pluralism as far as the principles of the political association are concerned, and that conceptions which refuse the principles of liberalism are to be excluded. I have no quarrel with him on this issue. But this is the expression of an eminently political decision, not of a moral requirement.. ${ }^{167}$ Mouffe concludes: 'The political is always constitutive - which is precisely what liberalism denies. ${ }^{168}$

Secondly, the alleged impartiality of the predominant interpretation is grounded on the public-private law distinction. It is to Marx and the legal realists to whom we owe our awareness about the partiality of that divide. ${ }^{169}$ With its focus on the autonomous individual, certain forms of liberalism fail to identify the raison d'être of social rights, namely, the solidarity that justifies the duties and institutions required for its collective conceptualization.

The defenders of the reasonability criterion are enthusiastic as they can ground allegedly progressive outcomes on a legal device that would deliver beyond political ideology. The purpose of the reasonable/unreasonable distinction purports to appeal to anyone impartially, beyond left and right. But that is not the case. As Fernando Atria states, such an interpretation is simply a different partisan position. ${ }^{170}$ For it is a completely partial view, one where the poor are deprived of the same treatments the rich can access while at the same time this latter group is entitled to the right to secede from the public healthcare system and access a special system designed exclusively for them. That view is perfectly consistent with the - certainly not neutral - philosophies that require the provision of minimum standards for the poorest by means of targeted policies. ${ }^{171}$ The reasonability criterion only allows for distinctions within one segment of society (differences between the poorest and the poor). That is certainly an example of the principle of equality. What is far from clear, however, is that such a notion can be established beyond ideological contestation or that it delivers the redistributive justice issues social rights require.

\subsubsection{The TAC case}

The $T A C$ case assessed the measures adopted by the South African government in relation to its programme to combat HIV. More specifically, it focused on

\footnotetext{
167 Mouffe, Paradox (n 165) 25.

168 ibid.

169 Juan Amaya Castro, 'Human Rights and the Critiques of the Public-Private Distinction' (DLaws thesis, Vrije Universiteit Amsterdam 2010) 39-42, 43-51.

170 Atria, Forma (n 85) 321.

171 Oscar Feo, 'Las Políticas Neoliberales y su Impacto sobre la Formación en Salud Pública. Comentarios sobre la Experiencia Venezolana' (2008) 3(4) Medicina Social
} 275, 276. 
the measures to combat the mother-to-child transmission of this virus. The measures included the administration of a drug called nevirapine which significantly reduced the risk of transmission, but it was to be applied exclusively at hospitals and clinics within research and training sites. These sites included two per province: one in a rural area, and another located in an urban area.

According to the applicants' contentions, the government's prohibition to provide nevirapine to public hospitals and clinics outside the research and training facilities would not be reasonable considering that the drug was free and that it would be unavailable for a very vulnerable segment of the population. ${ }^{172}$ Secondly, the applicants requested the government to have a comprehensive national programme to prevent mother-to-child transmission of HIV including voluntary counselling and testing, antiretroviral therapy and the option of substitute feeding. ${ }^{173}$ These two claims were grounded on two fundamental constitutional provisions - sections 27 and 28. ${ }^{174}$ These provisions were the source of positive and negative obligations that the State was obliged to fulfil. ${ }^{175}$

Importantly, the judgment shows the inexistence of disagreement between the government, the applicants and the court with respect to the comprehensiveness public health measures were expected to have. Nor was the issue about whether a specific group of people was deprived of an important good, or whether such a deprivation did not affect their lives, or whether they were poor. The issue at stake was whether the government's restrictions on nevirap-

$172 T A C$ (n 152) paras 48, 71; as admitted by Byrne (Iain Byrne, 'Enforcing the Right to Health: Innovative Lessons from Domestic Courts' in Mary Robinson and Andrew Clapham (eds), Realising the Human Right to Health (3 Rüffer and Rub 2009) 526), the free-of-cost nature of the drug was probably more important than is often noted as being one of the reasons triggering this decision.

$173 T A C$ (n 152) paras 45, 47.

174 '27(1) Everyone has the right to have access to: - (a) health care services, including reproductive health care ... (2) The State must take reasonable legislative and other measures, within its available resources, to achieve the progressive realisation of each of these rights.'; '28(1) Every child has the right - ... c) to basic nutrition, shelter, basic health care services and social services.'

175 In relation to the positive obligations, the Court stated that: 'sections 26 and 27 must be construed as imposing two positive obligations on the State: one an obligation to give effect to the 26(1) and 27(1) rights; the other a limited obligation to do so progressively through "reasonable legislative and other measures, within its available resources"'. Concerning the negative obligation, the Court cited Grootboom arguing that there was 'at the very least, a negative obligation placed upon the State and all other entities and persons to desist from preventing or impairing the right of access to adequate housing'. Such a negative obligation applied equally to s $27(1)$ on 'the right of access to "health care services, including reproductive health care"". TAC (n 152) paras 29,46 . 
ine could be considered reasonable and whether the government was obliged to have a comprehensive policy plan to prevent the mother-to-child transmission of HIV throughout the country. ${ }^{176}$ In this way, all the involved actors were approaching the issue from the perspective of public health, including whether the challenged statute affected public health, and whether granting the nevirapine treatment would or would not involve sacrificing other programmes already in place. In this respect, it was regarded as unreasonable not to provide nevirapine to the medical facilities outside the research and training sites, considering that the provision of the drug would not involve extra costs. ${ }^{177}$

The $T A C$ judgment engages in a non-individual approach to social rights. It shifts from an adjudication based on individual concerns, to one based on public health concerns. It thus ratifies the shift of paradigm adopted in Soobramoney. Still, the rather exceptional circumstances of the case must be noted. Usually, the administration of a treatment comes with, not without, costs. This made it simple for the Court to decide on the unconstitutionality of the government policy. The exceptionality of the lack of costs had the effect of ruling out the omnipresent background of scarcity against which social rights are usually considered. And with that, it took the polycentric dimension inherent in social rights adjudication out of the equation. In those circumstances, the lessons derived from the $T A C$ case and the reasonability standard may be more limited than what scholars have been suggesting.

\subsection{Portugal's 39/84 Case}

In this case, ${ }^{178}$ Portugal's Constitutional Court not only abided by the non-individual approach of social rights under solidarity, but it also interpreted the positive obligations deriving from the right to health in a way that seems to address the distinctive obligations of the right to health as described in the second half of chapter four.

The Court had to deal with a situation where the government attempted to regulate Portugal's National Healthcare Service (Serviço Nacional de Saúde, SNS). The government's regulation consisted of practically revoking the service. The Court established that the right to health had both a negative and a positive dimension. The negative dimension entailed that the State had to abstain from any act capable of threatening the health of the individual. The

176 Minister of Health and Others $v$ Treatment Action Campaign and Others [2002] ZACC 16, 2002 (5) SA 703, paras 4-5.

$177 T A C$ (n 152) para 71.

178 Case 39/84 Acórdão do Tribunal Constitucional no 39/84, 11 April 1984 in 'Acórdãos do Tribunal Constitucional', $3^{\circ}$ Vol (1984) 95ff (Portugal's Constitutional Court). 
positive dimension involved an entitlement to several State measures related to the prevention and treatment of illnesses. ${ }^{179}$ The SNS was the main means of realizing the positive dimension of the right of access to health. ${ }^{180}$ The Court added that it was not just any means of realization but 'the first'. In that sense, it stated that the creation of the SNS was a constitutive element of the right to health, and a State duty. ${ }^{181}$ Thus, the Court struck down Article 17 of Decree-Law Number 254/82 of 29 June 1982, which had amended Act of Parliament $\mathrm{N}^{\circ} 56 / 79$ of 15 September 1979, which had in turn established the SNS. The Court held that the amendment was equivalent to eliminating the SNS. ${ }^{182}$

When facing the question of whether the SNS could be abolished, the Court stated that that depended on the nature of the constitutional duty imposed by the constitution on the State, in the sense of establishing a national healthcare service as a means to realize the right to health. ${ }^{183}$ Further, the Court stated that the abolition of the SNS would create a situation of lack of compliance by the State to a concrete constitutional duty. Insofar as such an action would entail revoking the implementation of a fundamental right, the abolition of the SNS would involve a State violation of the constitutional right to health. ${ }^{184}$ By the same token, the Court stated that an amendment of an institution, service or legal body cannot take place by means of it being abolished. This conclusion would flow naturally from understanding this service as a guarantee for the realization of this right. ${ }^{185}$ Following the same line of argument, the Court stated that the SNS, once created, could not be abolished. Once created, the SNS became part of the right to health. As such, it was irreversible (except by a constitutional amendment). ${ }^{186}$

In sum:

(a) Portugal's Constitutional Court questioned the government's decision to interpret the constitutional right to health through a statute that was in fact revoking Portugal's single-tiered healthcare system. The case shows that the judiciary on some rare occasions has taken up the challenge to directly protect and fulfil the right to health taking a perspective consistent with solidarity. In doing so, the court applied a non-individualistic

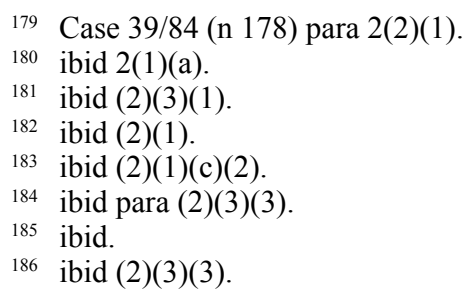


approach of social rights - it struck down an act of Parliament in order to maintain access to healthcare for all rather than just to a group;

(b) While the court did not actively come up with a different arrangement, it did reinstall a legislative provision that permitted the maintenance of a more extensive form of healthcare provision where access was arranged based on citizenship and medical need (as opposed to ability to pay). While the court's ruling was a reaction to Decree-Law Number 254/82, its effect consisted of reinstating Act of Parliament $\mathrm{N}^{\circ}$ 56/79. The court, therefore, did not base its decision on mere activism, but protected the right to health within the contours of a negative legislature;

(c) While the court exclusively based its decision on the narrative of constitutional rights, the decision can also be understood as a choice between two standards of healthcare decommodification: the one from Act of Parliament $\mathrm{N}^{\circ}$ 56/79 and the one from Decree-Law Number 254/82. That process involved the Court assessing the situation ex-ante and ex-post the entry into force of Decree-Law Number 254/82. Although not explicit in the judgment, since after the entry into force of Decree-Law Number 254/82 the SNS would be abolished and access to healthcare in Portugal would move much closer to a commodity, the judiciary preferred a less commodified access to healthcare. The decision of the Court distributes scarcities among all members of society, not on the condition of ability to pay but according to citizenship and medical need. In effect, the court recognized positive obligations from the right to health in line with solidarity.

Finally, this perspective may sound similar to the prohibition of retrogression developed by General Comment 3. ${ }^{187}$ This provision establishes that 'deliberately retrogressive' measures are required to be 'fully justified by reference to the totality of the rights provided for in the Covenant and in the context of the full use of the maximum available resources'. ${ }^{188}$ While there may be a certain overlap with that view, the notion of non-retrogression does not reproduce the non-individualistic nature of the right to health as a social right. Potentially, reducing the amount or quality of any individual or group entitlement could involve retrogression. ${ }^{189}$ Such a remedial development would not be in line

\footnotetext{
187 UNCESCR, Comment 3 (n 5) para 9.

188 ibid.

189 In the context of the Spanish administrative doctrine, Juli Ponce Sole has interpreted that retrogression is linked with the idea of a core individual minimum of rights. In his view, when combined with human dignity, those retrogressions are regarded as unconstitutional at all times. Juli Ponce Solé, El Derecho y la (Ir)reversibilidad Limitada de los Derechos Sociales y de los Ciudadanos. Las Líneas Rojas
} 
with the non-individual notion of social rights defended in the second half of chapter four. A justification of judicial powers of review in line with the solidarity-based concept of social rights focuses on the distributive standards (of economic nature) based on which the solidarity of the healthcare system is construed. This standard does not entail a discussion about the coverage of a greater or lesser number of healthcare treatments, but a discussion concerning the principles or logic on which scarcity is distributed: either due to legitimate trade-offs or due to inability to pay.

Non-retrogression could refer to the individual benefits that either a person or a group of persons may end up losing because of legitimate trade-offs. Such a focus would not necessarily be aligned with the principles of distributive justice that solidarity helps to put forward. Hence, any individual treatment that is cut due to a legitimate prioritization could be regarded as unlawful. Social rights would be identified based on whether they allow for securing more or fewer goods or services in the hands of one or more individuals. As stated previously, what defines social rights is a democratic standard that turns the given human right into a protected public good so that it can be assigned equally to all. ${ }^{190}$

\section{CONCLUDING REMARKS}

The invigoration of judicial powers is often seen as a development that automatically leads towards a better protection of rights. Examining salient cases in the field of access to healthcare, this chapter critically addressed this assumption in the context of the protection of the right to health. Two important ways for courts to address the right to health were considered. First as an individual right (through both indirect and direct protection), and secondly through the non-individualistic approach of solidarity.

Concerning indirect protection, a set of cases ruled on by the Inter-American Court of Human Rights reflected that the right to health tends to become a sub-species or an appendix of other rights. Even if recent case law has identified the limitations of the indirect approach, its inability to move beyond formal equality fails to connect with solidarity. Concerning the direct individual protection of the right to health, cases such as Meza Garcia or T-737, showed a rather essentialist protection which in the context of polycentric legal problems is difficult to implement. While being a step forward in terms

Constitucionales a los Recortes y la Sostenibilidad Social (Instituto Nacional de Administración Pública 2013) 24, 61, 66.

190 Ricardo García Manrique, La Libertad de Todos: Una Defensa de los Derechos Sociales (El Viejo Topo 2013) 34. 
of taking the right to health seriously, these approaches can lead to medicalized approaches of healthcare where the accent is placed on curative care. Similarly, it is unclear how these approaches could integrate the diverse and opposed needs and trade-offs that are embedded in healthcare systems. As the financial sustainability of healthcare systems may then come under threat, the study was also critical of this focus.

In what I consider an approach closer to the perspective of solidarity, I also addressed a further set of right-to-health cases. What courts do in these cases is to consider the right to health in a more collective way. Various cases from South Africa's Constitutional Court were assessed, and unlike the collateral effort or the direct appeal to human dignity, the case law here represents a qualitative shift as it acknowledges the non-individualistic nature of social rights. The right to health goes beyond an individual or group entitlement and appears strongly connected to public health. The study is critical, however, of the reasonability standard. As the regressive tendencies of the market provision of healthcare services are untouched, the interrogations raised by solidarity remain unaddressed in this perspective.

The 39/84 case that came before Portugal's Constitutional Court is, however, different. Besides implicitly identifying the non-individualistic and non-marketed nature of the right to health, the judiciary, while combining respect for the democratic pedigree of social rights, characterized the essence of this human right by defending the public nature of the entitlements created by the national healthcare system. Thus, solidarity can be used to bring the notion of the progressive realization of the right to health to the legal fore. In the judicial sphere, solidarity is a standard through which courts can give substance to the progressive realization of the right to health. ${ }^{191}$ In this respect, solidarity constitutes the continuing path towards the decommodification of access to healthcare in order to attain the goal of equal access to healthcare for all.

Matching the solidaristic challenging of the commodification of healthcare and the protection of the integrity and comprehensiveness of the national healthcare system, this last case law demonstrates what the protection of the social and collective dimension of the right to health consists of. As portrayed in this decision, this social dimension is not anymore one with the lower status of an aggregated demand, but one capable of imposing itself over other relevant economic interests and claiming autonomously for itself a fundamental legal status.

191 ICESCR (n 14) art 2(1). 